Studia nad Autorytaryzmem i Totalitaryzmem 41, nr 4 Wrocław 2019

DOI: 10.19195/2300-7249.41.4.1

\title{
MAŁGORZATA ŁUSZCZYŃSKA
}

ORCID: 0000-0002-4387-8820

Uniwersytet Marii Curie-Skłodowskiej w Lublinie

\author{
ARTUR ŁUSZCZYŃSKI \\ ORCID: 0000-0002-1589-935X \\ Uniwersytet Rzeszowski
}

\section{Wojna sprawiedliwa a nie święta. Średniowieczne koncepcje konfliktów zbrojnych}

\section{Wprowadzenie. Źródła koncepcji wojen sprawiedliwych w średniowieczu}

Średniowieczne spojrzenie na zagadnienie wojny zakorzenione jest zarówno w tradycji biblijnej (głównie ewangelicznej), jak i w myśli politycznej i prawnej starożytności ${ }^{1}$.

Myśliciele epoki średniowiecza znali ludzką naturę, mieli pełną świadomość jej skażenia grzechem i nie dążyli w sposób bezpośredni jedynie do usprawiedliwienia wojen. Ich działalność nakierowana była przede wszystkim na ograniczenie konfliktów zbrojnych oraz humanitaryzację działań wojennych. Stąd określenie „wojna sprawiedliwa” jako jedyna dopuszczalna, gdyż obwarowana licznymi przesłankami uznanymi za conditio sine qua non jej wszczęcia i prowadzenia. W myśli mediewistycznej można wyróżnić ujęcie bellum iustum sensu largo oraz sensu stricto; wąskie ujęcie prowadzi bezpośrednio do bellum iustissimum. Ścisłe

${ }^{1}$ Autorzy, zdając sobie w pełni sprawę, że każda periodyzacja jest zabiegiem sztucznym, budzącym polemikę naukową i kontrowersje, przyjęli ramy czasowe średniowiecza za K. Celleriusem. Ów profesor uniwersytetu w Halle określił ramy średniowiecza na lata 303-1453, to jest od wstąpienia na tron Konstantyna Wielkiego do zdobycia Konstantynopola przez Turków. Uczynił to w pracy z 1688 roku, zatytułowanej Historia universalis brevier ac perspicue expositia in antiquam aevi ac novam divisa. Periodyzacja mimo wszelkich mankamentów ma walor porządkujący. Szerzej o ramach czasowych najdłuższej epoki zob. T. Manteuffel, Historia powszechna. Średniowiecze, Warszawa 2012, s. 6-8. 
rozgraniczenie między wojną świętą a sprawiedliwą nie zawsze jest jednak możliwe. W ramach niniejszego artykułu, dokonując rozróżnienia, posłużono się kryterium celu i ideałów, w imię których toczone były działania zbrojne.

Myśliciele chrześcijańscy — bo do tych będziemy się głównie odwoływać — odnosząc się do problematyki wojny, nawiązywali przede wszystkim do Nowego Testamentu:

Miłujcie nieprzyjaciół waszych; dobrze czyńcie tym, którzy was nienawidzą; błogosławcie tym, co was przeklinają, i módlcie się za tych, którzy was oczerniają. Jeśli cię kto uderzy w policzek, nadstaw mu i drugi. Jeśli bierze ci płaszcz, nie broń mu i szaty ${ }^{2}$.

W myśli średniowiecznej odwoływano się zatem do przykazania miłości bliźniego, miłowania wrogów, zasady powstrzymywania się od odpłacania złem za zło. Przedstawiciele doktryn wieków średnich czerpali także inspirację ze formułowanych przez siebie wypowiedzi z pism myślicieli antycznych. Wpływy greckie oraz rzymskie są bowiem jasne i czytelne, w szczególności Platona, Arystotelesa oraz Marka Tuliusza Cycerona.

$\mathrm{Na}$ kształt koncepcji wojny świętej silnie oddziaływała doktryna Platona. Ten wybitny uczeń Sokratesa wskazywał na potrzebę prowadzenia wojen z barbarzyńcami, które miały na celu zapewnienie Grekom umiłowanego pokoju. Jednocześnie nie aprobował wojen między greckimi polis. O podjęciu działań zbrojnych oraz ich przebiegu powinni decydować ci, którzy posiedli cnotę, wiedzę i mądrość, czyli filozofowie. Oni doskonale zdawali sobie sprawę z tego, że tym, co najlepsze w polityce, ,nie jest ani wojna, ani bunt [...], lecz pokój oraz życzliwość wzajemna"3.

Wojna niejednokrotnie jawi się starożytnym myślicielom jako środek wiodący do pokoju. Pokój stoi wysoko w hierarchii aksjologicznej i bywa osiągany w wyniku działań wojennych. „Wszak niekiedy wojnę traktuje się właśnie jako warunek osiągnięcia pokoju”" . Maksyma „si vis pacem para bellum” zawarta jest w konstatacjach Platona i Arystotelesa. W pierwszej księdze Praw Platona czytamy:

Ten, kto na szczęście państwa i jednostki zapatruje się w ten sposób, nie będzie nigdy prawdziwym mężem stanu, jeżeli tylko lub przede wszystkim wojnę zewnętrzną będzie miał na oku,

${ }^{2}$ Łk 6, 27-29. Por. Mt 5, 43. Cytaty z Biblii przywoływane w niniejszym artykule pochodzą z Pisma Świętego Starego i Nowego Testamentu, oprac. zespół biblistów polskich z inicjatywy Benedektynów Tynieckich, wyd. 3, Poznań 1991. W odniesieniu oznaczenia cytatów z pism antycznych i średniowiecznych co do zasady będziemy się posługiwać numerami bocznymi lub innymi oznaczeniami (jak na przykład w wypadku Sumy teologicznej — część, kwestia, artykuł), które umożliwią zainteresowanemu czytelnikowi odszukanie szerszej partii tekstu bez względu na datę, miejsce czy język publikacji.

3 Platon, Prawa, przeł. M. Maykowska, Warszawa 1997, s. 19.

${ }^{4}$ M. Michalik, Moralność a wojna, Warszawa 1972, s. 33. 
ani też sumiennym nie będzie prawodawcą, jeżeli nie ze względu na pokój wydawać będzie ustawy dotyczące wojny, lecz ze względu na potrzeby wojenne organizować sprawy pokoju ${ }^{5}$.

W Etyce nikomachejkiej Arystoteles stwierdza natomiast: „Prowadzimy wojnę, by zażywać pokoju”6. Podobnie pisze w Polityce. Wojna ma prowadzić do pokoju: „Ustawodawca powinien się starać o to, by ustawodawstwo dotyczące zagadnienia wojny [...] podporządkować interesom życia spokojnego i pokoju"7.

Pokój jest zatem nadrzędnym celem działań wojennych ${ }^{8}$. Zaprowadzenie pokoju jako jedyne kryterium dopuszczalności wojen przewiduje również Cycero. W De officiis oraz De republica używa terminu bellum iustum na oznaczenie uprzednio zapowiedzianych działań zbrojnych zmierzających do odzyskania zrabowanego mienia czy obrony granic państwowych. Filozof ten korzystał z dorobku intelektualnego myśli helleńskiej. W swoich rozważaniach w przedmiocie konfliktów zbrojnych zarysował nowatorską koncepcję wojny sprawiedliwej. Duży nacisk kładł na oficjalne rozpoczęcie wojny. Bellum iustum musi być wypowiedziana, ponieważ podstęp nie licuje z etyką państwa i nie jest zgodny z cnotą obywatelską: ,Żadna wojna nie jest sprawiedliwa, jeśli nie toczy się dla odzyskania dóbr albo nie została wcześniej wypowiedziana"9.

\section{Dialektyka wojna-pokój}

Dwa dialektyczne pojęcia: wojna-pokój, naszkicowane w antyku i poddane analizie w średniowieczu, odnoszą się do człowieka jako członka społeczności politycznej ukształtowanej zgodnie z wzorcami kulturowymi epoki. Wydawać by się mogło, że zagadnienie pokoju jako cel ludzkich dążeń, a nawet sens ludzkiej egzystencji cieszyło się w myśli prawnej oraz politycznej średniowiecza większym zainteresowaniem niż wojna. Analiza tekstów źródłowych wskazuje jednak na zdecydowanie większe zainteresowanie myślicieli średniowiecznych wojną niż pokojem.

Idea pokoju miała w myśli mediewistycznej charakter mistyczny. Postrzegana była jako ,stan harmonii” w ludzkiej duszy oraz w stosunkach międzyludzkich, czyli harmonii wyznaczanej przez relację człowieka do Stwórcy. Pokój nie był zatem ściśle skorelowany z zagadnieniem wojny. Inaczej rzecz ujmując problematyka wojny kształtowała się niezależnie do idei pokoju. Owszem wojna to działania sprzeczne z pokojem, ale pokój to coś więcej niż tylko brak działań wojennych.

5 Platon, Prawa, s. 19.

${ }^{6}$ Arystoteles, Etyka nikomachejska, przeł. D. Gromska, Warszawa 2011, $1177 \mathrm{~b}$.

${ }^{7}$ Arystoteles, Polityka, przeł. L. Piotrowicz, Warszawa 2011, 1334a.

8 „Celem wojny jest pokój, a celem pracy spoczynek” — ibidem.

9 M.T. Cycero, De officiis. With an English Translation by Walter Miller, London 1913, I, 11, 36, https://archive.org/details/deofficiiswithen00ciceuoft (dostęp: 20.05.2019). 
W tym miejscu pojawia się pytanie: jak ów pokój osiągnąć? Jakimi metodami dojść do celu, jakim jest ład, spokój, stabilność czy poczucie bezpieczeństwa?

W poszukiwaniu odpowiedzi na te i inne pytania zrodziła się, a następnie rozwinęła idea wojny sprawiedliwej. Był to oczywiście proces złożony, a kamieniem milowym, swoistym katalizatorem, stał się edykt Konstantyna. Pierwsze wieki chrześcijaństwa wiązały się z prześladowaniami wyznawców Jezusa, którzy z niechęcią odnosili się do używania przemocy, rozlewu krwi na drodze dochodzenia do sprawiedliwości. Z nastawieniem antyrewolucyjnym, antywojennym wczesnego chrześcijaństwa wiąże się niechętny stosunek do służby wojskowej oraz dezaprobata względem udziału duchownych w starciach zbrojnych. Takie stanowisko było uzasadnione postrzeganiem wojen prowadzonych przez cesarstwo rzymskie jako działań zaborczych, a więc niesprawiedliwych, zbrodniczych. W miarę wzrostu znaczenia chrześcijaństwa jako religii uznawanej przez państwo wczesnochrześcijański pacyfizm traci na apodyktycznym charakterze, a od IV wieku powoli łagodnieje ${ }^{10}$.

Po tak zwanym edykcie mediolańskim chrześcijanie jako pełnoprawni obywatele cesarstwa rzymskiego ,poczuli na swych barkach obowiązek obrony porządku społecznego oraz obrony granic" ${ }^{11}$. W pewnych okolicznościach wojna została uznana za dopuszczalną, a nawet więcej — za konieczną, jeśli była niezbędna dla zachowania lub przywrócenia pokoju. Taka konieczność wzięła górę nad Ewangelią ${ }^{12}$. Proces ten miał oczywiście charakter ewolucyjny.

W IV i V wieku chrześcijanie prowadzili liczne dyskusje, których temat można sprowadzić do pytania: czy „rozpoczęcie wojny oznacza odrzucenie nauk Chrystusa, aby »miłować nieprzyjacioły swoje «"? ${ }^{13}$ Chrześcijańscy teologowie perfekcyjnie znali Stary Testament, tradycję wojny świętej i doskonale pamiętali obraz Pana Zastępów wzywającego do wojen z nieprzyjaciółmi swojego ludu, a także czyny dokonywane przez Mojżesza, Abrahama, Jozuego, Samona, Jeftego, Gedeona, Dawida czy Judę Machabeusza. Przeciw działaniom zbrojnym nadal wypowiadali się między innymi Laktancjusz, Jan Chryzostom i Grzegorz z Nysy. W ten sposób kontynuowano myśl Tertuliana i Orygenesa, którzy głosili, że miecz i krew nie mogą być znakiem obrony chrześcijaństwa ${ }^{14}$. Kto zadaje

${ }^{10}$ L. Winowski, Stosunek chrześcijan pierwszych wieków do wojny, Lublin 1947, s. 49-50.

11 J. Pałucki, Stowo wstępne, [w:] Wojna sprawiedliwa? Przestanie moralne Kościoła, red. J. Nagórny, M. Pokrywka, Lublin 2003, s. 21.

12 Ibidem.

13 P. Partner, Wojownicy Boga, Warszawa 2000, s. 75.

14 Co prawda Tertulian w Apologii $(30,4)$ dopuszcza działania wojenne o charakterze obronnym, to w późniejszym dziele De idolotaria (19) jednoznacznie i kategorycznie potępia jakąkolwiek przemoc. „Rozbrajając Piotra, Pan rozbroił wszystkich żołnierzy. Żaden stan nie jest dla nas dozwolony, jeśli naraża na niegodziwe czyny" - Tertulian, De Idolatria, I, 61, http://www.tertullian.org/latin/de_idololatria.htm (dostęp: 20.05.2019). Por. idem, Apology. De Spectaculis. Minucius Felix: Octavius, przeł. T.R. Glover, G.H. Rendall, London 1931, https://archive.org/details/ apologydespectac00tertuoft (dostęp: 20.05.2019). 
cierpienie dla obrony wiary, ten w rzeczywistości jej nie broni, lecz występuje przeciw jej przykazaniom ${ }^{15}$. Chrześcijanin może jedynie modlitwą wspierać jedną ze stron konfliktu, ale nigdy nie może tego czynić mieczem ${ }^{16}$ : „Zadawanie śmierci jest zakazane [...]. Zawsze zakazane jest zabijanie człowieka, gdyż Bóg chciał, aby życie było święte"17.

Zwolennicy prowadzenia wojen w imię pokoju powoływali się na argumenty zaczerpnięte z Pisma Świętego, w których zawód żołnierza nie tylko nie podlegał krytyce, lecz bywał gloryfikowany. Jan Chrzciciel mówił do żołnierzy: „Nad nikim się nie znęcajcie i nikogo nie uciskajcie, lecz poprzestawajcie na swoim żołdzie" ${ }^{18}$. Chrystus pochwalił wiarę setnika ${ }^{19}$, a Dzieje Apostolskie wiarę setnika Korneliusza ${ }^{20}$.

Z czasem z idei starochrześcijańskiego pacyfizmu zrodziła się koncepcja pax christiana, na podstawie której ukształtowała się idea wojny sprawiedliwej oraz wojny świętej. Kościół zachodni, dążąc do zachowania ładu feudalnego, głosił obowiązek poszanowania zasad chrześcijańskiej moralności w imię „,pozostawania w łączności z Bogiem"21. Skoro pokój miał zabezpieczać ówczesny ład i porządek społeczny, to działania zmierzające do jego utrzymania nie były już uważane za niewłaściwe czy niegodne chrześcijanina.

Nie uważano więc za sprzeczne z pokojem wypraw zbrojnych przeciw muzułmanom w Hiszpanii, wypraw krzyżowych do Ziemi Świętej, wyprawy wojskowej przeciw albigensom w południowej Francji ani wojen przeciw husytom w Czechach i na Morawach. [...] wyprawy były uważane za pokojowotwórcze, ponieważ przyczyniały się do umocnienia stanowiska papiestwa i całego ówczesnego porządku społeczno-politycznego ${ }^{22}$.

Takiego stanowiska nie podzielali Franciszek z Asyżu czy papież Celestyn V. Ich poglądy w zakresie problematyki wojen nie wpłynęły jednak na kształtowanie opinii publicznej ówczesnego świata ani nie miały znaczącego wpływu na doktrynę polityczną czy prawną epoki ${ }^{23}$.

15 Klemens Aleksandryjski określał wojnę jako działanie demonów; zob. idem, Stromata, przeł. J. Niemirska-Pliszczyńska, t. 1, Warszawa 1994, V, 126, 5.

16 Por. Orygenes, Przeciw Celsusowi, [w:] Pisma starochrześcijańskich pisarzy, przeł. S. Kalinkowski, Warszawa 1977, s. 269-270. „Przekuliśmy na sierpy włócznie, którymi kiedyś walczyliśmy, nie wyciągamy już miecza przeciwko żadnemu z narodowi, [...] gdyż przez Chrystusa zostaliśmy synami pokoju" - ibidem, V, 33.

${ }^{17}$ Lanktantius, De divinis institutionibus, [b.m.w. 1497], VI, 20, https://archive.org/details/ ita-bnc-in1-00000224-001 (dostęp: 20.05.2019).

18 Łk 3,14

19 Łk 7, 1-10; Mt 8, 5-13.

${ }^{20}$ Dz 10,1-2.

21 J. Keller, Katolicka doktryna społeczna, Warszawa 1989, s. 213.

22 Ibidem, s. 214.

${ }^{23}$ Koncepcja pax christiana zaczęła załamywać się w połowie XIII wieku — rozpoczęły się walki między mieczem a pastorałem, czyli między władzą duchowną a świecką, o polityczne wpływy (vide walki toczone z cesarzem Fryderykiem II, a następnie z królem francuskim Filipem IV). 
Tak kształtowało się stanowisko, że pokój stoi wysoko w chrześcijańskiej aksjologii, lecz nie jest wartością najwyższą. Za cenę wojny, życia ludzkiego należało bronić wiary oraz zgodnego z „wolą Bożą" porządku wewnętrznego czy między narodami. Teoria wojny sprawiedliwej wywodzi się zatem z teologii średniowiecznej i odegrała zasadniczą rolę w kształtowaniu doktryn mediewistycznych.

\section{Wojna sprawiedliwa jako słuszne działania zbrojne obwarowane enumeratywnie określonymi czynnikami}

Wielu Ojców i Doktorów Kościoła pochwalało działania zbrojne podejmowane w celu obrony własnego kraju. Biskup Mediolanu, święty Ambroży, ,jako pierwszy z Ojców Kościoła całkowicie usprawiedliwił wojnę toczoną w obronie ojczyzny przeciwko barbarzyńcom i w obronie społeczeństwa przeciwko zbójcom"24. Atanazy Wielki zaś twierdził, że ,zabójstwo nieprzyjaciela w sprawiedliwej wojnie jest czynem godnym pochwały"25. Święty Ambroży, wiążąc męstwo z cnotą sprawiedliwości, pisał: „Przecież i męstwo, które bądź w czasie wojny broni ojczyzny od barbarzyńców, bądź w czasie pokoju ujmuje się za słabymi, bądź sprzymierzeńców bierze w obronę przed łupieżcami - pełne jest sprawiedliwości”"26.

Do teologów i kanonistów, którzy przyczynili się do rozwoju koncepcji wojen sprawiedliwych, należy zaliczyć przede wszystkim Izydora z Sewilli (De Bello et Ludis), Anzelma z Lukki (Defensio pro Gregorio VII, Contra Guibertum antipapam) Ivona z Chartres (Decretum, Panormia, Collectio Tripartia), Gracjana (Concordia discordantium canonum) i Rajmunda z Pennafort (Summa Cassuam). Jan z Legnano (Tractatus de Bello) wyszczególnił przyczyny toczonych wojen oraz zakres oddziaływania działań wojennych (na tej podstawie wyróżnił siedem rodzajów wojen, w tym cztery sprawiedliwe i trzy niesprawiedliwe).

Myśliciele doby wieków średnich wiązali odpowiedź na agresję w postaci wojny obronnej z zasadami ius gentium, prawami naturalnymi oraz maksymą vim vi repellere omnia iura permittunt. Samo rozumienie wojny nie jest zbyt precyzyjnie ujęte w myśli średniowiecza. Pod pojęciem „wojna” rozumiano bowiem nie tylko konflikt między państwami, lecz także prywatne utarczki, konflikty między osobami prywatnymi, wszelkie akty gwałtu i przemocy, a nawet starcia gladiatorów. Dopiero w XIII stuleciu precyzyjnie znaczenie terminu „wojna” określił święty Tomasz z Akwinu ${ }^{27}$.

${ }^{24}$ P. Contamine, Wojna w średniowieczu, Gdańsk-Warszawa 2004, s. 292.

25 Ibidem.

${ }^{26}$ Ambroży, De officiis ministrorum, I, 129 — św. Ambroży z Mediolanu, Obowiązi duchownych, przeł. K. Abgarowicz, Warszawa 1967.

27 Św. Tomasz z Akwinu, Suma teologiczna, przeł. A. Głażewski, Londyn 1967, II-II, q. 23-46. 
W przedmiocie użycia siły fizycznej nauczanie Kościoła ukształtował z kolei święty Augustyn. Ten Ojciec i Doktor Kościoła katolickiego rozpoczął, jak słusznie zauważył Józef Borgosz, epokę sakralizacji wojen ${ }^{28}$. Na doktrynę augustiańską oddziaływał niewątpliwie idealizm obiektywny Platona oraz sytuacja polityczna cesarstwa rzymskiego pustoszonego przez najazdy barbarzyńców. Pokój jest darem Boga. Augustyn z Hippony wyróżnia pokój doskonały oraz możliwy do zaprowadzenia w rzeczywistości. Idealny pokój możliwy jest do urzeczywistnienia tylko w Królestwie Niebieskim. Pokój powszechny natomiast — pax omnium rerum - polega na ładzie i harmonii w świecie, w szczególności między narodami, które nie powinny z sobą konkurować, lecz współpracować, wzajemnie się wspierając i służąc sobie pomocą. Jest to zatem pokój niemal doskonały, możliwy do urzeczywistnienia w ramach Civitas Dei. Do takiego stanu rzeczy człowiek wierzący powinien dążyć, zmagając się z pokusami i osobistymi ambicjami. Pax civitatis, pokój wewnątrzpaństwowy, polega zaś na harmonijnym współżyciu członków społeczności państwowej.

Wojna co do zasady jest nośnikiem wszelkiego zła, cierpienia, bólu i łez. Jej pierwszoplanowym celem jest pokój. Pozostałe racje uzasadniające działania wojenne są drugorzędne i muszą być podporządkowane celowi zasadniczemu: „U prawdziwych czcicieli Boga takie wojny są dobre, które prowadzi się nie z zaciekłości czy okrucieństwa, lecz dla uzyskania pokoju"29.

Święty Augustyn jest realistą, zna ludzką naturę skażoną grzechem oraz ludzkie słabości. Nie ma zatem złudzeń co do możliwości przekucia wszystkich mieczy na lemiesze: „Nigdy żaden naród nie osiągnął takiego bezpieczeństwa, aby nie musiał obawiać się najazdów zagrażających jego życiu" ${ }^{30}$. Należało więc pozostawić miejsce w myśli politycznej i prawnej wojnie, której w pewnych sytuacjach nie można uniknąc ${ }^{31}$. Staje się ona czasami koniecznością. W De civitate Dei czytamy:

Lecz mędrzec będzie wiódł tylko sprawiedliwe wojny. [...] Bo niesprawiedliwość strony przeciwnej zmusza mędrca do staczania wojen sprawiedliwych. A ponieważ jest to niesprawiedliwość ludzka, winien nad nią ubolewać każdy człowiek, chociażby nawet nie wynikała z niej konieczność prowadzenia wojny ${ }^{32}$.

28 J. Borgosz, Drogi i bezdroża filozofii pokoju, Warszawa 1989, s. 57.

${ }^{29}$ Św. Augustyn, De Verbis Domini, 23, q. 1 - Augustinus, Sermones de verbis Domini, de verbis apostoli Pauli, nec non de verbis Epistolarum Canonicarum, [Utrecht 1462, manuskrypt], http://objects.library.uu.nl/reader/index.php?obj (dostęp: 20.05.2019).

30 Św. Augustyn, De civitate Dei, przeł. W. Kubicki, Kęty 1998, XVII, 13.

${ }^{31}$ Należy podkreślić, że Augustyn z Hippony konsekwentnie potępiał wszelkie okrucieństwa, występki czy nadużycia popełniane podczas wojny — idem, Contra Faustum, 22, 74-75 — św. Augustyn, Przeciw Faustowi, przeł. J. Sulowski, Warszawa 1991; idem, De civitate Dei, 3, 10; 4, 15; 4, $44 ; 6,10 ; 15,4 ; 19,7 ; 22,6$.

32 Św. Augustyn, De civitate Dei, 19, 7. 
Niechęć do wojny potęgowała się u świętego Augustyna — jak pisze Wiktor Kornatowski: „,pod koniec życia wystąpił on przeciwko wojnie namiętnie i gwałtownie, przedstawiając ją jako zbrodnię i rozbój”"33. Uważał, że należy raczej zabijać wojnę słowem, niż tocząc ją, żelazem zabijać ludzi ${ }^{34}$.

Sprawiedliwa wojna jawi się zatem przede wszystkim jako walka o sprawiedliwość, spokój i ład. Chrześcijaństwo ma uczynić ją mniej okrutną przez eliminację zbędnej przemocy, okrucieństwa, represji i profanacji miejsc kultu religijnego. Święty Augustyn opowiadał się za litością dla jeńców wojennych. Należy przy tym pamiętać, że w doktrynie tego myśliciela niesprawiedliwość może być dopustem Bożym i cierpliwe znoszenie jej może wywołać skruchę w sercu złoczyńcy bardziej niż postawa agresywna. Tak w praktyce realizować by się mogły słowa świętego Pawła skreślone w Liście do Rzymian: „zło dobrem zwyciężaj”35.

$\mathrm{Na}$ fundamencie doktryny augustiańskiej w pierwszej połowie XII wieku zrodziła się „scholastyczna doktryna wojny"36. Jej geneza wiąże się ze studiami prawa rzymskiego przez jurystów z Bolonii oraz z publikacją Dekretu Gracjana (około $1140 \mathrm{roku}$ ). Mimo drobnych różnic w podejściu do wojny sprawiedliwej w ramach tak zwanej doktryny scholastycznej można - dokonując generalizacji — stwierdzić, że była to myśl jednolita. Przysłużyła się ona sformułowaniu w kolejnym stuleciu klasycznych kryteriów wojny sprawiedliwej: persona, res, causa, animus i auctoritas. Pojęcia te zdefiniował już Laurencjusz, a powtórzył Jan Teutończyk, rozpowszechnił zaś święty Rajmund z Pennafort. Ten ostatni z wymienionych myślicieli jasno i wyraźnie sformułował podstawowe zasady prowadzenia wojen, do których należy: ściśle określony cel — odebranie zagarniętej własności lub odparcie napaści; ostateczność działań zbrojnych — możliwość ich podjęcia jedynie po wyczerpaniu wszelkich środków pokojowych; oraz podmiot wypowiadający wojnę - zwierzchnik polityczny, a zatem legalna władza państwowa (za niedopuszczalne uznał wojny prywatne) ${ }^{37}$.

Koncepcję wojen sprawiedliwych rozwinął święty Tomasz z Akwinu. Mimo że wojnie sprawiedliwej poświęcił jedynie kwestię Summy teologicznej ${ }^{38}$, to zasadność użycia siły, zastosowania przymusu można zrekonstruować na podstawie analizy całego dorobku tego myśliciela. Tomasz kontynuuje myśl świętego Augustyna na drodze doprecyzowania i uzupełnienia jego doktryny. Stawiając zasadnicze pytanie o sprawiedliwość wojny, porusza kwestię udziału duchownych, możliwości posługiwania się podstępem, prowadzenia walk w dni świąteczne.

33 W. Kornatowski, Społeczno-polityczna myśl św. Augustyna, Warszawa 1965, s. 192. Za „burzycieli i wrogów pokoju nie uważano wiernych katolików stosujących się do nakazów Kościoła, lecz odstępców, heretyków, schizmatyków i tych wszystkich, którzy usiłowali podkopać istniejący wówczas ustrój polityczny i społeczny" — ibidem.

${ }^{34}$ Ibidem.

${ }^{35} \mathrm{Rz} 12,21$.

36 P. Contamine, op. cit., s. 310.

${ }^{37}$ L. Ehrlich, Polski wykład prawa wojny XV wieku, Warszawa 1955, s. 57.

38 Św. Tomasz z Akwinu, Suma teologiczna, II-II, q. 40. 
Wyraźnie definiuje — o czym już wspomniano — pojęcie „,wojna”: „Wojna w ścisłym znaczeniu jest przeciw wrogowi zewnętrznemu jako starcie społeczności ze społecznością" ${ }^{39}$. Tym samym odróżnia wojnę od zwady, która ,jest starciem między jednostkami lub małymi grupami" ${ }^{40}$. Wojną nie są zatem ani tak zwane wojny domowe, ani akty tyranobójstwa. Działania wojenne zasługują zdaniem Akwinaty na miano sprawiedliwych, jeśli łącznie spełniają następujące warunki:

- legitima auctoritas - w zakresie problematyki podmiotu wypowiadającego wojnę wyraźne nawiązanie do świętego Augustyna ${ }^{41}$, myśliciel dodaje, że zwierzchnik polityczny musi kierować się ideą bonum commune, inicjując działania wojenne. Prawo wypowiadania wojny związane jest z zapewnieniem opieki i ochrony poddanym;

- causa iusta - słuszna przyczyna, czyli naprawienie doznanych krzywd, których sprawca nie chce naprawić dobrowolnie; w tym zakresie podmiot sprawujący władzę powinien dokonać kalkulacji zysków i strat, brać pod uwagę szkody i krzywdy, jakie przyniosą działania wojenne;

- intentio recta - intencja walczących, ich uczciwy zamiar realizacji dobra w praktyce szeroko rozumianego życia społecznego (ewentualnie zapobieganie złu); Tomasz przekonuje, że „nieprzyjaciele są naszymi bliźnimi”, zwraca też uwagę na niebezpieczeństwo zmiany ról w teatrze wojny oraz przestrzega przed łatwością przemiany obrońcy w agresora, który popełnia okrucieństwa dla samych okrucieństw, grabi, plądruje, okalecza kobiety, dzieci i starców.

Zagadnienie moralności $\mathrm{w}$ ramach konfliktów zbrojnych jako conditio sine qua non wojny pretendującej do miana sprawiedliwej kontynuował hiszpański teolog i prawnik Francisco de Vitoria, którego poglądy zostały spopularyzowane przez szkołę w Salamance. Z kolei dopiero co przedstawione warunki wojny sprawiedliwej uporządkował i usystematyzował Francisco Suárez ${ }^{42}$.

Do tak ukształtowanej doktryny wojny sprawiedliwej odwoływali się w XV stuleciu przedstawiciele Akademii Krakowskiej. Ich refleksja nad problematyką dopuszczalności działań zbrojnych miała wymiar praktyczny, ponieważ wiązała się z realnymi stosunkami geopolitycznymi. W pismach Stanisława ze Skarbimierza czy Pawła Włodkowica skupia się jak w soczewce średniowieczny dyskurs w przedmiocie bellum iustum - bellum sacrum $^{43}$.

${ }^{39}$ Ibidem, II-II, q. 42, a 1.

40 Ibidem.

${ }^{41}$ Św. Augustyn, Contra Faustum, 22, 74.

42 Szerzej zob. Z. Kuderowicz, Filozofia o szansach pokoju. Problemy wojny i pokoju w filozofii XX wieku, Białystok 1995, s. 170.

43 Szerzej zob. Paweł Włodkowic et al., Prawo ludów i wojna sprawiedliwa, Warszawa 2018; E.A. Wesołowska, Paweł Włodkowic - współczesne znaczenie pogladów i dokonań, Płock 2001; R.M. Zawadzki, Spuścizna pisarska Stanisława ze Skarbimierza. Studium źródłoznawcze, Kraków 1979. 


\section{Wojna święta — „wojna przez Boga autoryzowana”}

Obok pojęcia wojny sprawiedliwej w literaturze przedmiotu występuje pojęcie wojny świętej, postrzeganej jako swoiste misterium. „Wojny przez Boga autoryzowane" opierają się na swoistym systemie aksjologicznym, którego zwieńczeniem są wartości eschatologiczne ${ }^{44}$.

Początkowo wojna sprawiedliwa miała charakter uniwersalny w odniesieniu do zasad, na jakich się opierała. Nadawała podmiotowość wszystkim uczestnikom, niezależnie od ich przynależności do wspólnoty chrześcijańskiej ${ }^{45}$. Z czasem - jak pisze Zbigniew Rau — w wojnie sprawiedliwej „w swej dojrzałej formie ów uniwersalizm zamienił się w ekskluzywizm" 46 . Kategorię wojny sprawiedliwej zaczęto odnosić do starć między ludami chrześcijańskimi, natomiast działania zbrojne przeciw innowiercom, poganom i heretykom zaczęto traktować wręcz jako obowiązek religijny. Z tego względu Józef Maria Bocheński wyróżnił dwa rodzaje wojen świętych: w szerokim znaczeniu „każda wojna słuszna jest święta”, w wąskim ujęciu święta to ta „dla obrony praw Boskich i wolności spełniania obowiązków religijnych" 47 .

Wojna święta wykazuje bliskość z wojną sprawiedliwą, aczkolwiek została ona wzbogacona o wątki biblijne i eschatologiczne. Jej istotą stała się obrona miejsc świętych kalanych przez niewiernych albo pomoc współbraciom w wierze cierpiącym na skutek ucisku niewiernych, gardzących prawami boskimi. Można uznać, że wojny określane jako bellum sacrum narodziły się wraz z apelem papieża Aleksandra II, który w 1063 roku Ojciec Święty skierował władców chrześcijańskich Europy w przedmiocie pomocy Hiszpanii w walce z muzułmanami ${ }^{48}$. Doktrynalnego uzasadnienia wojen świętych należy poszukiwać już w myśli świętego Augustyna: „nie wypada wątpić, czy to, że wojna, której podjęto się w oparciu o powagę Boga, jest prowadzona słusznie celem zgniecenia, ukrócenia

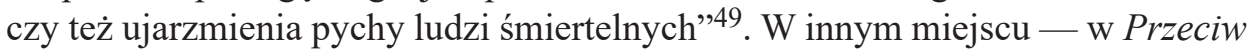
Faustowi - filozof pisze: ,niewinnie prowadzi wojny ten, kto walczy z rozkazu Boga, bo każdy, kto Jemu służy, musi wiedzieć, iż On nie może nakazać nic złego" ${ }^{50}$. Wspomnieć należy, że również święty Ambroży łaskawym okiem spoglądał na wojny prowadzone przeciw barbarzyńcom wyznającym arianizm ${ }^{51}$. Na-

${ }^{44}$ Pojęciem „wojen autoryzowanych przez Boga” posłużył się Leszek Winowski, Stosunek chrześcijaństwa pierwszych wieków do wojny, Lublin 1947; por. M. Michalik, op. cit., s. 184.

${ }^{45}$ Z. Rau, T. Tulejski, Wojna sprawiedliwa versus wojna święta. Zagadnienia doktrynalne historycznej konfrontacji, [w:] Bellum iustum versus bellum sacrum. Uniwersalny spór $w$ refleksji średniowiecznej. Konstatacja 1414-1418, red. Z. Rau, T. Tulejski, Toruń 2014, s. 211.

46 Ibidem.

47 J.M. Bocheński, Szkice etyczne, Londyn 1953, s. 108-110.

48 M. Michalik, op. cit., s. 185-186.

49 Św. Augustyn, Contra Faustum, XXII, 74.

50 Ibidem, I, 75.

51 Ambroży, De officiis ministrorum, I, 27. 
tomiast odnosząc się do zastąpienia przez Konstantyna po 317 roku rzymskiego orła przez labarum ze splecionymi inicjałami greckiego wyrazu Christos, święty Ambroży pisał: „Nawrócili się, Panie, i zwracają sztandary ku Twej wierze. To już nie orły wojskowe ani lot ptaków prowadzi wojsko, ale Panie Jezu, Twoje imię i cześć, jaka jest Ci oddawana" 52 .

W ten sposób u schyłku XI wieku krucjaty przybrały kształt ruchu masowego kierującego się zawołaniem „Deus vult!”. Sama idea wojny świętej zakorzeniona jest w tradycji starotestamentalnej. W Księga Wyjścia czytamy: „Pan, mocarz wojny, Jahwe jest imię jego” $(15,3)$ oraz „Ponieważ podniósł rękę na tron Pana, dlatego trwa wojna Pana z Amalekitą z pokolenia w pokolenie" $(17,16)$, w Księdze Powtórzonego Prawa $(32,41-42)$ zaś:

Gdy miecz błyszczący wyostrzę

I wyrok wykona ma ręka,

Na swoich wrogach się pomszczę, odpłacę tym, którzy Mnie nienawidzą.

Upoję krwią moje strzały,

Mój miecz napasie się mięsem,

Krwią poległych i uprowadzonych,

Głowami dowódców nieprzyjacielskich.

Kościół w ramach wojny świętej jawił się jako nowy Izrael, a „chrześcijanom z woli samego Boga należne są więc tereny Ziemi Świętej, teraz, podobnie jak w czasach Jozuego, zasiedlone przez sługi zła skazane na wytępienie" 53 . $\mathrm{Z}$ czasem wojna święta zyskała charakter ofensywny. Stała się bellum iustissimum i zmierzała do odzyskania Ziemi Świętej postrzeganej jako królestwo Chrystusowe. Stała się zatem obowiązkiem średniowiecznego rycerza. Namiestnik Chrystusa, papież, miał władzę ogłoszenia wojny świętej i wezwania całego rycerstwa zachodniego do udziału w krucjacie. Koncepcja wojny świętej mocno oddziaływała na kształtowanie etosu rycerza i zwyczaje rycerskie związane na przykład z poświęceniem zbroi i miecza, pasowaniem na rycerza (zwane „ósmym sakramentem" z uwagi na oprawę religijną) czy istnieniem zakonów rycerskich ${ }^{54}$.

[W]itraże, freski, rzeźby i kapitele zarówno romańskie, jak i gotyckie zawierają w znacznej części motywy wojenne: walczących zbrojnych, rycerzy z chorągwiami, mieczami, wierzchowcami. Sławna rzeźba w Reims przedstawia uzbrojonego rycerza z czepcem od kolczugi na głowie, ze złożonymi rękami, przyjmującego komunię od księdza. Ówczesne armie posiadały liczne wizerunki o treści religijnej. Broń mogła być zaopatrzona w pobożne inskrypcje; miecz, zwany mieczem świętego Maurycego, przechowywany w skarbcu cesarskim w Wiedniu, ozdobiony jest słowami: Homo Dei. In nomine Domini. Cristus Vincit Reinat. Cristus Imperat. [...] Warto zaznaczyć, że krzyże z materiału — o różnych barwach i kształtach — służyły, począwszy od XIV wieku, jako znaki odróżniające wojowników angielskich, francuskich, bretońskich,

52 Cyt. za: P. Contamine, op. cit., s. 292.

53 Z. Rau, T. Tulejski, op. cit., s. 213.

54 J. Keller, op. cit., s. 218. 
burgundzkich i lotaryńskich, co stanowiło kontynuację zwyczaju pochodzącego niewątpliwie z pierwszej krucjaty ${ }^{55}$.

W tym zakresie widać wyraźne sprzężenie zwrotne - sztuka wojenna oddziaływała na sztukę sakralną, a religia na kształtowanie się zwyczajów wojennych i tradycji wojskowych. Bitwy poprzedzane były bogatą oprawą religijną: licznie czynione znaki krzyża, spowiedź, komunia, liturgia. Po starciu zbrojnym zaś następowały nabożeństwa żałobne, pochówek zmarłych, a zwycięzcy odprawiali msze dziękczynne i niejednokrotnie trofea przekazywali jako wota kościołom lub sanktuariom. Nierzadko zwycięzcy walnych bitew fundowali opactwa, kościoły bądź skromne kapliczki. Hierarchia kościelna wykazywała skłonność do gloryfikowania, a nawet sakralizacji cnót wojennych. W obliczu zagrożenia longobardzkiego, a później saraceńskiego głowa Kościoła zapewniała o wiecznym zbawieniu dla tych, którzy chwycą za broń w obronie Kościoła rzymskiego.

Tak zatem wojna święta, wyrastająca na podbudowie augustiańskiej wojny sprawiedliwej, przybrała zdecydowanie inny kształt niż w doktrynie świętego Augustyna - nie tylko nie obrażała już Boga, ale wręcz ma być Mu miła. Walka uczestników takiej wojny była chwalebna, wysoce etyczna i zjednująca łaskę Bożą.

Doktryna wojny sprawiedliwej stanowi zatem fundament, na którym wzniesiono konstrukcję wojny świętej. Bellum iustum w doktrynie politycznej oraz prawnej średniowiecza miała głównie na celu ograniczanie działań wojennych oraz — w wypadku ich nieuchronności - humanitaryzacje poczynań militarnych. Instytucja wojny sprawiedliwej, w kształcie nadanym przez myśl wieków średnich, stała się podstawą uregulowań z zakresu prawa międzynarodowego.

\section{Bibliografia}

\section{Źródła}

Ambroży, De officiis ministrorum - Ambroży z Mediolanu św., Obowiązki duchownych, przeł. K. Abgarowicz, Warszawa 1967.

Arystoteles, Etyka nikomachejska, przeł. D. Gromska, Warszawa 2011.

Arystoteles, Polityka, przeł. L. Piotrowicz, Warszawa 2011.

Augustinus, Sermones de verbis Domini, de verbis apostoli Pauli, nec non de verbis Epistolarum

Canonicarum, [Utrecht 1462, manuskrypt], http://objects.library.uu.nl/reader/index.php?obj.

Augustyn św., Contra Faustum - Przeciw Faustowi, przeł. J. Sulowski, Warszawa 1991.

Augustyn św., De civitate Dei, przeł. W. Kubicki, Kęty 1998.

Augustyn św., De Verbis Domini

Cycero M.T., De officiis. With an English Translation by Walter Miller, London 1913, https://archive.org/details/deofficiiswithen00ciceuoft.

Klemens Aleksandryjski, Stromata, przeł. J. Niemirska-Pliszczyńska, t. 1-2, Warszawa 1994.

55 P. Contamine, op. cit., s. 330-331. 
Lanktancjusz, De divinis institutionibus, [b.m.w. 1497], https://archive.org/details/ita-bnc-in1-00000224-001.

Orygenes, Przeciw Celsusowi, [w:] Pisma starochrześcijańskich pisarzy, przeł. S. Kalinkowski, Warszawa 1977.

Paweł Włodkowic, Stanisław ze Skarbimierza, Benedykt Hesse, Mateusz z Krakowa, Prawo ludów $i$ wojna sprawiedliwa, przeł. J. Łukaszewska-Haberko, Warszawa 2018.

Pismo Święte Starego i Nowego Testamentu, oprac. zespół biblistów polskich z inicjatywy Benedektynów Tynieckich, wyd. 3, Poznań 1991.

Platon, Prawa, przeł. M. Maykowska, Warszawa 1997.

Tertulian, Apology. De Spectaculis. Minucius Felix: Octavius, przeł. T.R. Glover, G.H. Rendall, London 1931, https://archive.org/details/apologydespectac00tertuoft.

Tertulian, De idolotaria, http://www.tertullian.org/latin/de_idololatria.htm.

Tomasz z Akwinu św., Suma teologiczna, przeł. A. Głażewski, Londyn 1967.

\section{Opracowania}

Bocheński J.M., Szkice etyczne, Londyn 1953.

Borgosz J., Drogi i bezdroża filozofii pokoju, Warszawa 1989.

Contamine P., Wojna w średniowieczu, Gdańsk-Warszawa 2004.

Ehrlich L., Polski wyktad prawa wojny XV wieku, Warszawa 1955.

Keller J., Katolicka doktryna społeczna, Warszawa 1989.

Kornatowski W., Spoleczno-polityczna myśl św. Augustyna, Warszawa 1965.

Kuderowicz Z., Filozofia o szansach pokoju. Problemy wojny i pokoju w filozofii XX wieku, Białystok 1995.

Manteuffel T., Historia powszechna. Średniowiecze, Warszawa 2012.

Michalik M., Moralność a wojna, Warszawa 1972.

Pałucki J., Słowo wstępne, [w:] Wojna sprawiedliwa? Przesłanie moralne Kościoła, red. J. Nagórny, M. Pokrywka, Lublin 2003.

Partner P., Wojownicy Boga, Warszawa 2000.

Rau Z., Tulejski T., Wojna sprawiedliwa versus wojna święta. Zagadnienia doktrynalne historycznej konfrontacji, [w:] Bellum iustum versus bellum sacrum. Uniwersalny spór w refleksji średniowiecznej. Konstatacja 1414-1418, red. Z. Rau, T. Tulejski, Toruń 2014.

Wesołowska E.A., Paweł Włodkowic - współczesne znaczenie pogladów i dokonań, Płock 2001.

Winowski L., Stosunek chrześcijan pierwszych wieków do wojny, Lublin 1947.

Zawadzki R.M., Spuścizna pisarska Stanisława ze Skarbimierza. Studium źródłoznawcze, Kraków 1979.

\section{A JUST WAR, NOT A HOLY WAR: MEDIEVAL CONCEPTS OF ARMED CONFLICT}

\section{Summary}

The aim of the article is to point out that medieval thinkers, when referring to holy wars or just (righteous) wars, did not seek to justify armed conflicts. The authors hereof claim that the activities of philosophers of the Middle Ages were aimed at restricting armed conflicts and focused on making the hostilities more humanitarian. Therefore, a "just war" was a war guarded by a number of precon- 
ditions which constituted a mandatory condition. The idea of a just war was rooted in the biblical tradition (mainly in the New Testament) and in the ancient legal thought. The medieval concept of war affected, among other things, the formation of the knight's ethos and habits of war.

Keywords: armed conflict, holy war, medieval.

Małgorzata Łuszczyńska

m.luszczynska@poczta.umcs.lublin.pl

Artur Łuszczyński

pan.artur.luszczynski@gmail.com 